\title{
Effect of incorporation of lemongrass extract and lemongrass oil on the sensory, physico-chemical and textural profile of paneer
}

\author{
Krupa Joseph and K Jayaraj Rao
}

Received: 09 November 2018 / Accepted: 22 January 2019 / Published online: 18 April 2019

(C) Indian Dairy Association (India) 2019

\begin{abstract}
Paneer represents a variety of Indian soft cheese, highly nutritious and wholesome, used as a base material for the preparation of a large number of culinary dishes. Due to the ever growing demand of paneer by varied health conscious consumers, it is necessary to develop value added varieties of paneer. Lemongrass is an aromatic perennial tall tropical grass and yields an aromatic oil consisting citral as its major component. This study evaluated the effect of addition of natural lemongrass extract and oil on the sensory, physico-chemical and textural profile of paneer. Lemongrass leaves and oil were incorporated of the following ways: i) cut and crushed leaves into milk@0,2, 4 and 6\%(w/v) ii) cut and crushed leaves into the coagulant (citric acid) solution @ 20\% (w/v); iii) Extraction of lemongrass leaves in potable water followed by heat concentration and dipping of paneer blocks in the concentrate; iv) Addition of lemongrass oil into milk used for paneer preparation as well as into the coagulant solution (citric acid) at various levels $(0,0.015$, 0.02 and $0.025 \%$ ). The samples with lemongrass extract as well as oil obtained satisfactory sensory scores. On the basis of sensory scores, it was found that the addition of lemongrass leaves in cut form into milk was found to be the optimized step in the process of lemongrass flavoured paneer manufacture. The textural and physico-chemical properties of paneer were altered only to a
\end{abstract}

\footnotetext{
Krupa Joseph $(\square)$

Dairy Technology Section, ICAR-National Dairy Research Institute (SRS), Adugodi, Bengaluru-560 030, India

E-mail: krupa.joseph22@gmail.com; Phone: +919400336034

K Jayaraj Rao

Dairy Technology Section, ICAR-National Dairy Research Institute

(SRS), Adugodi, Bengaluru-560 030, India
}

small extent with increased level of addition of lemongrass into paneer. It is concluded from the present study, that lemongrass has improved the flavour and sensory attributes of paneer and holds the potential for development of value added dairy products.

Keywords: Flavouring agent, Lemongrass, Paneer, Value addition, Sensory acceptance

\section{Introduction}

Paneer is an important heat and acid coagulated indigenous dairy product of India, used as a base material for the preparation of various culinary dishes and snacks (Mathur et al., 1991). The global paneer market grew at a compound annual growth rate (CAGR) of around 6.7\% from 2009-2016 and reached a volume of 1.6 million metric tonnes in the year 2016, according to 'Indian Dairy Industry Database 2018-2023', and News report provided by Research and Markets. Due to the ever growing demand of paneer by varied health conscious consumers, it became necessary to develop value added varieties of paneer. The bland taste of paneer is another major concern affecting its consumer acceptability, which can possibly be resolved by the incorporation of natural extracts from herbs, spices and grasses during the preparation of paneer. In recent years, consistent efforts have been made for the manufacture of value added varieties of paneer by adopting advanced technology and by the addition of novel additives including vegetables, herbs and spices.

Herbs and spices have been used for thousands of centuries by many cultures to enhance the flavour and aroma of foods. There has been increasing demand for the addition of herbs and spices to food and dairy products, due to possible chances of improvement of flavour and increased shelf life with no toxic effects when compared with chemical preservatives (Oraon et al., 2017). Being natural foodstuffs, herbs and spices appeal to consumers who tend to question the safety of synthetic additives. Madsen and Grypa (2000) reported that herbs and spices are desirable food ingredients to create and explore new tasty products. Herbs and spices are currently used mainly for 
enhancing the flavour of foods rather than extending shelf life (Almeida et al., 2000). Bajwa et al. (2005) reported that incorporation of coriander and mint at level of $10 \%$ by weight in paneer improved the overall acceptability score and yield of product. In addition to imparting flavour, certain herbs prolong the shelf life of foods due to their bacteriostatic or bactericidal activity and prevent rancidity by their antioxidant activity (Shelef et al., 1980). Turmeric was incorporated into paneer@ of $0.6 \%$ by weight of expected yield of paneer prepared and was found to be acceptable and safe for usage (Singh et al., 2014).

Lemongrass is an aromatic perennial tropical grass, termed by our ancients as a "sacred herb". It is widely used as an essential ingredient in Asian cuisines because of its sharp lemon flavor. Lemongrass has high antioxidant capacity and free radical scavenging effect of hydro-alcoholic extract of Cymbopogon citratus was established (Rao et al., 2009). Lemongrass extracts (by direct boiling and distillate) have been successfully utilized in yoghurt manufacture at 4 levels $(1 \%, 2 \%, 3 \%$ and $4 \%)$ with optimum level of $2 \%$ (Sutariya and Rao, 2015). Ready-to-serve whey based mango lemongrass beverage has been developed with the addition of lemongrass distillate varying from $0-2.5 \%$, with acceptable level of addition at 1.5\% (Sahu et al.,2005). Fresh Lemongrass extract was best for hiding the beany flavor in soy protein isolate solution and soy ice cream beany flavor. Moreover, the extract also improved the taste of soymilk (Natisri et al., 2014). Use of honey or lemongrass was excellent in masking the beany flavour, improving the taste and general acceptability of the soymilk (Laswai et al., 2009). Although lemongrass is Generally Recognized as Safe (GRAS) in the United States, there is no mention of lemongrass in FSSAI rules as yet. A suggested safe limit of the essential oil for humans (based on an experiment in rats) is $0.7 \mathrm{mg} / \mathrm{kg}$ body weight/day (Fandohan et al., 2008).

No work has been reported about the incorporation of lemongrass as a flavouring agent into paneer. Therefore, the present study was contemplated to evaluate the effect of incorporation of lemongrass as fresh leaf extract as well as oil on sensory quality, physico-chemical parameters, textural attributes, colour characteristics, anti-oxidant properties and compositional quality of paneer.

\section{Materials and methods}

For the preparation of paneer, fresh cow milk was procured from cattle yard of Southern Regional Station, ICAR-NDRI, Bengaluru, filtered and standardized to approximately 3.0\% fat and 8.5\% SNF. Fresh leaves of lemongrass (Cymbopogon flexosus) grown in the campus was used for the project work. Freshly extracted lemongrass oil was obtained from the Horticultural Section, University of Agricultural Sciences, GKVK, Bengaluru. Lowdensity polyethylene (LDPE) pouches were used during the storage studies.

\section{Preparation of paneer}

Paneer was prepared in the laboratory using method described by (Bhattacharya et al., 1971) with slight modification. Milk, standardized to $3.0 \%$ fat and $8.5 \%$ SNF was heated to $90^{\circ} \mathrm{C}$ without holding, cooled to $80{ }^{\circ} \mathrm{C}$ and coagulated by the addition of $2 \%$ citric acid solution at $80^{\circ} \mathrm{C}$. The citric acid was added slowly to milk with continuous agitation till clear whey separated out. The curd was allowed to settle for $5 \mathrm{~min}$. and the whey was drained out using a muslin cloth. The curd was then collected and filled in wooden hoop lined with clean muslin cloth. Pressure was applied on the hooped curd $4 \mathrm{~kg} / \mathrm{cm}^{2}$ for 20-25 minutes. The paneer block was then cooled by immersion in chilled water $\left(4\right.$ to $\left.6{ }^{\circ} \mathrm{C}\right)$ for $2 \mathrm{~h}$ for texturization. The paneer block was removed from chilled water and placed on wooden planks for 15 minutes thereby allowing the water to drain off. The air dried paneer was packed in LDPE pouches and stored in refrigerator $\left(7 \pm 2^{\circ} \mathrm{C}\right)$ for further analyses.

\section{Incorporation of lemongrass}

Lemongrass was incorporated into paneer by the following methods:

(1)Fresh lemongrass leaves were washed, and added in both cut form (3-5 cm long cuts) and crushed form (cuts were crushed in a mixer) and added to milk @ 0 (control), 2, 4 and 6\% by the weight of milk before heat treatment.

(2) Cut and crushed form of lemongrass leaves were added to citric acid solution@20\% by volume of coagulant solution.

(3) Fresh lemongrass oil was added to milk and coagulant solution @ 0 (control), 0.015, 0.020 and $0.025 \%(\mathrm{v} / \mathrm{v})$ before heat treatment of milk.

(4) Hot water extract of washed and cleaned lemongrass leaves (leaves in both cut and crushed forms added (@10\% by volume of water) was concentrated to half the volume, chilled and used for dipping the paneer.

Optimal levels of the ingredients used during standardisation of the process for preparation of lemongrass flavoured paneer were determined using sensory evaluation.

The paneer samples are abbreviated as follows:

T1: Lemongrass extract in milk (cut)

T2: Lemongrass extract in milk (crushed)

T3: Lemongrass extract in citric acid solution

T4: Dipping in lemongrass extract

T5: Lemongrass oil in milk 


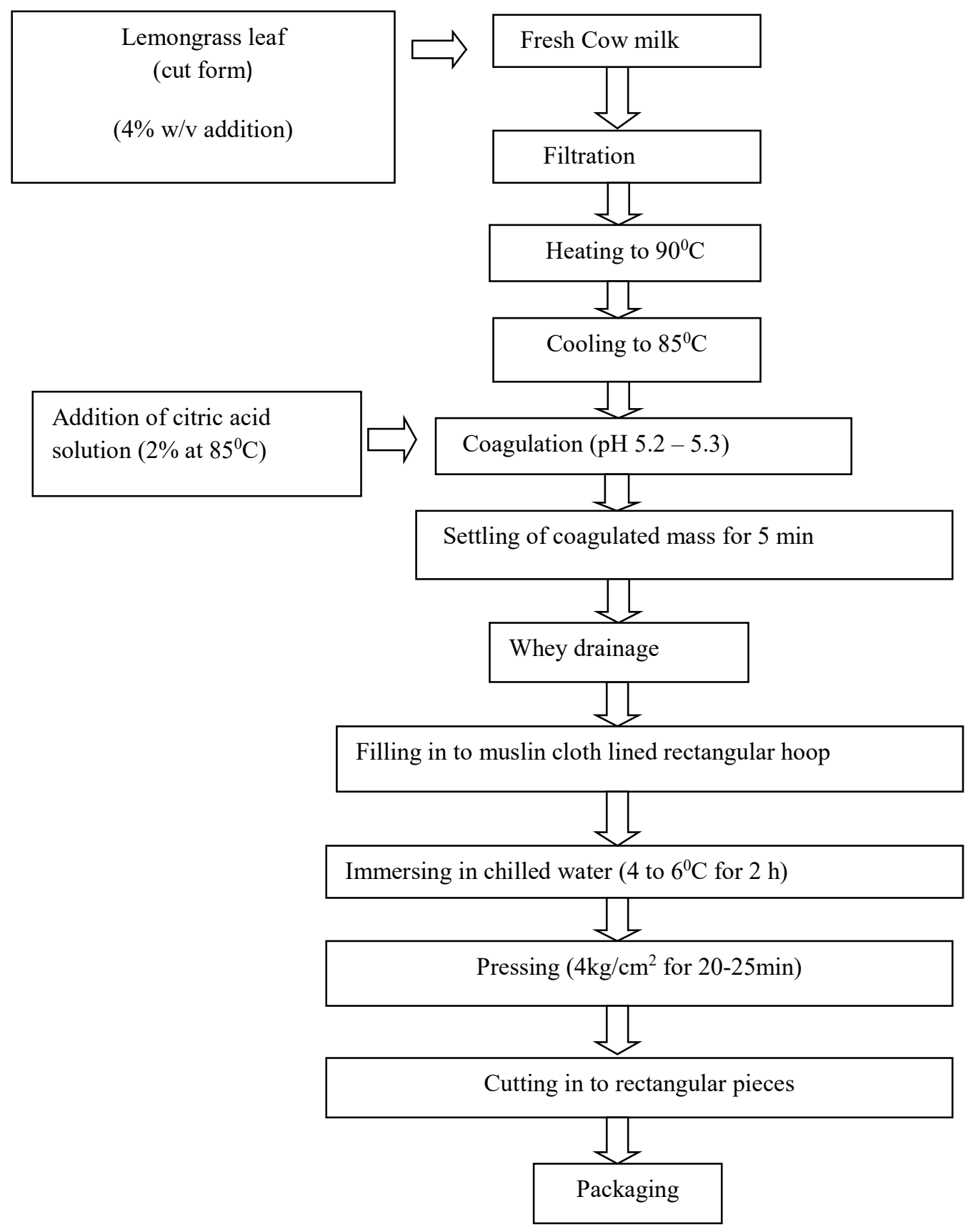

Fig .1 Optimized process for the manufacture of lemongrass flavoured paneer

T6: Lemongrass oil in citric acid solution

\section{Evaluation for sensory attributes}

Each block of paneer samples was cut into $1 \mathrm{~cm} \times 2 \mathrm{~cm}$ pieces (rectangular) and evaluated for sensory attributes like Colour and Appearance (CA), Body and Texture (BT), Flavour and Overall Acceptability (OA) by a sensory panel consisting of at least 6 members on a nine point hedonic scale (Amerine et al., 1967).

\section{Physico-chemical analysis}

Moisture content in paneer was determined according to BIS (1983) procedure specified for paneer under IS: 10484. Fat in paneer was analysed by Mojonnier-gravimetric method as per the method AOAC (2005). Total nitrogen or total protein in paneer was determined by standard micro Kjeldahl as described in AOAC (2005) with modification. Lactose was derived by difference. The Ash content of paneer was estimated by the method of BIS (1981). Acidity of the paneer sample was estimated according to BIS 
(1983) procedure under IS: 10484, specified for paneer. $\mathrm{pH}$ of paneer samples was measured as per the procedure described by (Awad et al. 2005). Colour measurement of the paneer samples was performed by Scanner-Adobe Photoshop (SAP) method (Vyawahare and Rao, 2011).

\section{Textural analysis}

The texture profile parameters such as hardness, cohesiveness, springiness and chewiness were determined as per the literature reported by Koca and Metin (2004) and (Mathare et al. 2009).

\section{Statistical analysis}

In order to select the method of incorporation of lemongrass, 3 replications were conducted for each trial. The values of each attribute under study were subjected to statistical analysis by one way ANOVA using SPSS Software 16.0. The significance of treatments effect was determined by Tukey test at $5 \%$ level of significance.

\section{Results and discussion}

\section{Effect of method of addition of lemongrass on sensory quality of paneer}

The data obtained for changes in sensory attributes of paneer with increasing rate of addition of lemongrass by various methods are presented in Table1. The CA score of the paneer with cut leaves extract, was enhanced from $8.04 \pm 0.15$ to $8.35 \pm 0.29$ and it remained at par with the control $(8.04 \pm 0.15)$ up to $4 \%$ of leaves utilization, thereafter the score reduced during further addition $(8.35 \pm 0.29$ to $8.00 \pm 0.22)$. BT was altered only to an insignificant extent throughout the addition. The flavour parameter was enhanced significantly $(\mathrm{P}<0.05)$ by the addition of cut lemongrass leaves, but $6 \%$ addition was found to be too harsh. The same trend was reflected in the OA score. The crushed form of lemongrass leaves when utilized @ $4 \%$ of milk for the preparation of paneer, the CA score of the paneer $(8.00 \pm 0.37)$ remained comparable to control $(8.06 \pm 0.33)$ after which it followed a sharp decline ( $8.0 \pm 0.37$ to $7.6 \pm 0.66$ ), which may be due to the fact that the use of $6 \%$ leaves imparted a darkish green colour to paneer which did not find better acceptance with the judges. Regarding BT, it may be noticed from the results in Table 1, that it remained unaffected throughout the different levels of addition of crushed lemongrass leaf (scores ranging from $7.85 \pm 0.43$ to $7.92 \pm 0.24$ ). The flavour parameter was enhanced by addition of lemongrass leaves, but $4 \%$ and $6 \%$ addition was found to be too harsh, resulting in grassy flavour in the product; hence significantly less flavour scores were obtained. The OA score for the control sample was $8.00 \pm 0.26$ which got enhanced to $8.02 \pm 0.14$ for $2 \%$ of crushed lemongrass leaves. Based on the sensory evaluation results, it was recommended that the extract of lemongrass leaves in cut form and crushed form could be used up to $4 \%$ by weight of milk and $2 \%$ by weight of milk respectively without any adverse effect on the CA and BT quality and with acceptable flavour quality.

The results of extraction of lemongrass flavour into citric acid solution by the addition of cut and crushed forms of lemongrass leaves@20\% by volume of citric acid solution, indicated that the addition imparted a significant $(\mathrm{P}<0.05)$ effect on the sensory quality of paneer sample. The CA score ranged from $7.85 \pm 0.34$ to $8.06 \pm 0.33$ in all the samples including control paneer. There was no significant $(\mathrm{P}>0.05)$ influence on the $\mathrm{BT}$ score of paneer, when lemongrass leaves extracted in citric acid solution were used for the coagulation of paneer. Flavour scores revealed that the acceptance of paneer was enhanced significantly $(\mathrm{P}<0.05)$ on addition of cut leaves of lemongrass because it imparted a pleasing lemony flavour to paneer when compared to the sweet acidic taste of control paneer. The OA scores also followed the same pattern. Statistical analysis of the results exhibited a significant influence of the form of addition of lemongrass leaves into citric acid solution on all the sensory parameters of paneer, except BT.

Concentrated and chilled lemongrass leaf extracts in both cut and crushed forms were used at the rate of $20 \%$ by volume of chilled water, for the dipping purpose of paneer. The CA score ( $7.99 \pm 0.19)$ of the paneer sample dipped in cut lemongrass leaf extract remained comparable to control $(8.00 \pm 0.30)$, whereas the use of crushed leaves imparted a yellowish green tinge which was less accepted among the judges, thereby reducing the CA score to $7.86 \pm 0.39$. Dipping of paneer in concentrated and chilled extract (cut leaves) imparted a sweet acidic flavour to paneer $(8.02 \pm 0.35)$ which was comparable to that of control paneer $(8.12 \pm 0.50)$, while the concentrated and chilled extract of crushed lemongrass leaves when utilized for dipping the paneer resulted in a slight grassy flavour, decreasing the flavour score from $8.02 \pm 0.35$ to $7.98 \pm 0.51$. The BT remained unaffected by the form of incorporation of lemongrass leaf and the rate of addition. The OA was higher for paneer dipped in cut lemongrass leaf extract than for the control paneer and the paneer dipped in crushed lemongrass leaf extract.

On the addition of lemongrass oil into milk for the manufacture of lemongrass flavoured paneer, the CA score of the treated paneer samples added with $0.020 \%$ lemongrass oil $(8.00 \pm 0.37)$ remained comparable to that of control (score $8.06 \pm 0.33$ ). Regarding BT, it may be noticed from the results presented in Table 1, that it remained unaffected throughout the levels of addition of oil (scores ranging from $7.85 \pm 0.43$ to $7.92 \pm 0.24$ ). The flavour score got enhanced (from $8.04 \pm 0.34$ to $8.10 \pm 0.27$ ) for $0.015 \%$ addition of lemongrass oil into milk, but the addition of $0.020 \%$ and $0.025 \%$ of lemongrass oil into milk imparted a harsh and unacceptable flavour, thus reducing the scores to $7.92 \pm 0.41$ and $7.48 \pm 0.46$, respectively. This shows that the addition of lemongrass oil @ $0.015 \%$ gave flavour score comparable to control and was statistically significant $(\mathrm{P}<0.05)$. Addition of higher amounts of 
lemongrass oil resulted in astringent flavour in the product; hence significantly less flavour scores were obtained for $0.025 \%$ addition. The same trend was reflected in the overall acceptance score. The OA score for the control sample was $8.00 \pm 0.26$ which increased to $8.08 \pm 0.24$ for the paneer sample prepared by adding $0.015 \%$ of lemongrass oil into milk followed by a significant $(\mathrm{P}<0.05)$ reduction for further levels of addition of lemongrass oil into milk. The statistical analysis of the data at 5\% level of significance indicated that all the sensory parameters were significantly $(\mathrm{P}<0.05)$ affected by use of lemongrass oil in milk which was in turn used for paneer preparation.

It was observed that when lemongrass oil was added to citric acid solution (coagulant) during the manufacture of paneer, the difference between the scores for CA of control and experimental samples was statistically insignificant which could be related to the fact that the addition of lemongrass oil in citric acid solution did not change the appearance and tint of the solution (Table 1). The same trend was observed for BT scores (ranging from $8.07 \pm 0.44$ to $8.11 \pm 0.50$ ). The flavour appeal was enhanced by the addition of lemongrass oil up to $0.02 \%$ into citric acid solution, but an addition of $0.025 \%$ imparted an unacceptable pungent flavour to the paneer sample. Based on the sensory evaluation results, it was revealed that lemongrass oil could be used @ $0.015 \%$ by weight of milk and $0.02 \%$ by volume of citric acid solution for flavour incorporation for paneer preparation without any adverse effect on CA and BT quality as the data revealed that CA scores of treated samples of paneer were at par with the control in all the levels of addition and also the addition of lemongrass oil did not have any impact on the body and texture attributes.

The statistical analysis of the results of sensory scores at 5\% level of significance indicated that the sensory parameters such as flavour and OA were significantly affected by the incorporation of lemongrass for flavouring purpose, by various methods,

without any adverse effect on BT quality, and with slight greenish tinge for samples added with cut and crushed lemongrass leaves into milk and when used for dipping purpose.

Table1 Sensory scores of paneer incorporated with lemongrass extract at different stages of preparation

\begin{tabular}{|c|c|c|c|c|}
\hline Attributes & Colour \& Appearance & Flavour & Body \& Texture & $\mathrm{OA}$ \\
\hline \multicolumn{5}{|c|}{ T1-Lemongrass extraction in milk (cut) } \\
\hline Control & $8.04 \pm 0.15^{\mathrm{a}}$ & $8.08 \pm 0.31^{\mathrm{c}}$ & $8.05 \pm 0.2^{\mathrm{a}}$ & $8.02 \pm 0.50^{\mathrm{c}}$ \\
\hline $2 \%$ & $8.11 \pm 0.21^{\mathrm{a}}$ & $7.83 \pm 0.36^{\mathrm{b}}$ & $7.96 \pm 0.49^{\mathrm{a}}$ & $7.79 \pm 0.40^{\mathrm{b}}$ \\
\hline $6 \%$ & $8.00 \pm 0.22^{\mathrm{a}}$ & $7.64 \pm 0.78^{\mathrm{a}}$ & $8.04 \pm 0.33^{\mathrm{a}}$ & $7.69 \pm 0.75^{\mathrm{a}}$ \\
\hline \multicolumn{5}{|c|}{ T2-Lemongrass extraction in milk (crushed) } \\
\hline $4 \%$ & $8.00 \pm 0.37^{\mathrm{c}}$ & $7.92 \pm 0.41^{\mathrm{b}}$ & $7.85 \pm 0.43^{\mathrm{a}}$ & $7.81 \pm 0.17^{\mathrm{b}}$ \\
\hline $6 \%$ & $7.60 \pm 0.66^{\mathrm{a}}$ & $7.48 \pm 0.46^{\mathrm{a}}$ & $7.88 \pm 0.37^{\mathrm{a}}$ & $7.03 \pm 0.45^{\mathrm{a}}$ \\
\hline \multicolumn{5}{|c|}{ T3-Lemongrass extraction in citric acid solution } \\
\hline Control & $8.06 \pm 0.33^{c}$ & $8.04 \pm 0.34^{\mathrm{c}}$ & $7.92 \pm 0.24^{\mathrm{a}}$ & $8.00 \pm 0.26^{\mathrm{c}}$ \\
\hline Cut & $7.85 \pm 0.34^{\mathrm{b}}$ & $7.92 \pm 0.18^{b}$ & $7.91 \pm 0.29^{a}$ & $7.88 \pm 0.21^{\mathrm{b}}$ \\
\hline Cut & $7.99 \pm 0.19^{\mathrm{b}}$ & $8.02 \pm 0.35^{b}$ & $8.01 \pm 0.32^{\mathrm{a}}$ & $8.25 \pm 0.31^{\mathrm{b}}$ \\
\hline Crushed & $7.86 \pm 0.39^{\mathrm{a}}$ & $7.98 \pm 0.51^{\mathrm{a}}$ & $8.02 \pm 0.21^{\mathrm{a}}$ & $7.98 \pm 0.48^{\mathrm{a}}$ \\
\hline \multicolumn{5}{|c|}{ 75Lemongrass oil in milk } \\
\hline Control & $8.06 \pm 0.33^{c}$ & $8.04 \pm 0.34^{\mathrm{c}}$ & $7.92 \pm 0.24^{\mathrm{a}}$ & $8.00 \pm 0.26^{\mathrm{c}}$ \\
\hline $0.015 \%$ & $7.85 \pm 0.34^{\mathrm{b}}$ & $8.10 \pm 0.27^{\mathrm{c}}$ & $7.91 \pm 0.29^{\mathrm{a}}$ & $8.08 \pm 0.24^{\mathrm{c}}$ \\
\hline $0.020 \%$ & $8.00 \pm 0.37^{\mathrm{c}}$ & $7.92 \pm 0.41^{b}$ & $7.85 \pm 0.43^{\mathrm{a}}$ & $7.88 \pm 0.37^{\mathrm{b}}$ \\
\hline $0.025 \%$ & $7.77 \pm 0.34^{\mathrm{a}}$ & $7.48 \pm 0.46^{\mathrm{a}}$ & $7.88 \pm 0.37^{\mathrm{a}}$ & $7.03 \pm 0.45^{\mathrm{a}}$ \\
\hline \multicolumn{5}{|c|}{ T6-Lemongrass oil in citric acid solution } \\
\hline Control & $8.00 \pm 0.43^{\mathrm{a}}$ & $8.00 \pm 0.40^{\mathrm{c}}$ & $8.07 \pm 0.44^{\mathrm{a}}$ & $8.00 \pm 0.45^{\mathrm{c}}$ \\
\hline $0.015 \%$ & $8.01 \pm 0.43^{\mathrm{a}}$ & $7.82 \pm 0.58^{b}$ & $8.08 \pm 0.11^{\mathrm{a}}$ & $7.78 \pm 0.50^{\mathrm{b}}$ \\
\hline $0.020 \%$ & $8.05 \pm 0.43^{\mathrm{a}}$ & $8.04 \pm 0.02^{\mathrm{c}}$ & $8.10 \pm 3.44^{\mathrm{a}}$ & $8.15 \pm 0.20^{c}$ \\
\hline
\end{tabular}

Note: Data represented as mean \pm standard deviation of three replications. Values with different superscripts in a row are significantly different $(\mathrm{p} \leq 0.05)$; OA-overall acceptance 
Optimization of the process of manufacture of lemongrass flavoured paneer

From various methods of incorporation of lemongrass, optimum sample has been selected based on sensory scores. When lemongrass was extracted into milk in cut form, $4 \%(\mathrm{w} / \mathrm{v})$ addition was found to be having the best score, whereas in crushed form,
$2 \%(\mathrm{w} / \mathrm{v})$ addition was seen to be optimum. Lemongrass when extracted into citric acid solution, the crushed form of addition obtained higher sensory scores than cut form, whereas for the method of dipping coagulum in concentrated and chilled lemongrass extract, the cut form was found to be good. In the addition of lemongrass oil in to milk, $0.015 \%$ addition was selected, while for addition of oil in to citric acid solution, $0.020 \%$ was chosen based on optimum sensory scores. All the selected

Table 2 Effect of the process of incorporation of lemongrass extract on the sensory scores of paneer

\begin{tabular}{llllllll}
\hline Attributes & Control & T1 & T2 & T3 & T4 & T5 & T6 \\
\hline Colour \& Appearance $8.24 \pm 0.25^{\text {bc }} 8.60 \pm 0.34^{\mathrm{c}}$ & $7.86 \pm 0.32^{\mathrm{ab}}$ & $7.96 \pm 0.06^{\mathrm{abc}}$ & $7.53 \pm 0.50^{\mathrm{a}}$ & $7.88 \pm 0.10^{\mathrm{ab}}$ & $7.97 \pm 0.38^{\mathrm{abc}}$ \\
Flavour & $8.20 \pm 0.20^{\mathrm{cd}}$ & $8.40 \pm 0.10^{\mathrm{d}}$ & $7.67 \pm 0.15^{\mathrm{bc}}$ & $7.01 \pm 0.30^{\mathrm{a}}$ & $7.29 \pm 0.25^{\mathrm{ab}}$ & $7.60 \pm 0.26^{\mathrm{b}}$ & $7.40 \pm 0.20^{\mathrm{b}}$ \\
Body \& Texture & $8.07 \pm 0.12^{\mathrm{a}}$ & $8.04 \pm 0.16^{\mathrm{a}}$ & $7.97 \pm 0.18^{\mathrm{a}}$ & $8.02 \pm 0.32^{\mathrm{a}}$ & $7.94 \pm 0.12^{\mathrm{a}}$ & $7.85 \pm 0.14^{\mathrm{a}}$ & $8.01 \pm 0.15^{\mathrm{a}}$ \\
OA & $8.13 \pm 0.12^{\mathrm{cd}}$ & $8.37 \pm 0.24^{\mathrm{d}}$ & $7.83 \pm 0.11^{\mathrm{bc}}$ & $7.31 \pm 0.15^{\mathrm{a}}$ & $7.46 \pm 0.25^{\mathrm{ab}}$ & $7.72 \pm 0.19^{\mathrm{b}}$ & $7.62 \pm 0.33^{\mathrm{ab}}$ \\
\hline
\end{tabular}

Note: Data represented as mean \pm standard deviation of three replications. Values with different superscripts in a row are significantly different $(\mathrm{p} \leq 0.05)$

Table 3 Effect of the method of incorporation of lemongrass extract on the physico-chemical attributes of paneer

\begin{tabular}{|c|c|c|c|c|c|c|c|c|}
\hline \multirow{2}{*}{$\begin{array}{l}\text { Attributes } \\
\mathrm{T} 1\end{array}$} & \multicolumn{2}{|c|}{ Acidity $(\%) \mathrm{pH}$} & \multirow[t]{2}{*}{ Yield $(\%)$} & \multicolumn{2}{|c|}{ Solid losses in whey (\%) } & \multicolumn{2}{|c|}{ Moisture (\%) L* } & \multirow[t]{2}{*}{$a^{*} \quad b^{*}$} \\
\hline & & & & & & & & \\
\hline Control & $0.33 \pm 0.09^{\mathrm{a}}$ & $5.97 \pm 0.03^{\mathrm{b}}$ & $17.04 \pm 0.21^{\mathrm{a}}$ & $5.61 \pm 0.14^{\mathrm{a}}$ & $52.65 \pm 0.70^{\mathrm{a}}$ & $90.29 \pm 0.19^{\mathrm{a}}$ & $-0.77 \pm 0.31^{\mathrm{a}}$ & $16.17 \pm 0.58^{\mathrm{a}}$ \\
\hline $2 \%$ & $0.42 \pm 0.03^{\mathrm{a}}$ & $5.94 \pm 0.03^{\mathrm{ab}}$ & $16.71 \pm 0.30^{\mathrm{a}}$ & $5.74 \pm 0.37^{\mathrm{a}}$ & $52.47 \pm 0.32^{\mathrm{a}}$ & $89.7 \pm 0.27^{\mathrm{a}}$ & $-0.64 \pm 0.12^{\mathrm{a}}$ & $16.94 \pm 0.47^{\mathrm{a}}$ \\
\hline $6 \%$ & $0.61 \pm 0.02^{b}$ & $5.90 \pm 0.02^{\mathrm{a}}$ & $16.26 \pm 0.53^{\mathrm{a}}$ & $5.82 \pm 0.40^{\mathrm{a}}$ & $52.29 \pm 0.32^{\mathrm{a}}$ & $83.3 \pm 0.18^{\mathrm{a}}$ & $-0.29 \pm 0.23^{\mathrm{a}}$ & $21.05 \pm 0.38^{c}$ \\
\hline \multicolumn{9}{|l|}{$\mathrm{T} 2$} \\
\hline $4 \%$ & $0.63 \pm 0.03^{b}$ & $5.94 \pm 0.04^{\mathrm{a}}$ & $16.60 \pm 0.92^{\mathrm{a}}$ & $5.97 \pm 0.50^{\mathrm{a}}$ & $54.73 \pm 0.39^{\mathrm{a}}$ & $92.28 \pm 0.22^{\mathrm{b}}$ & $-3.47 \pm 0.27^{\mathrm{a}}$ & $18.59 \pm 0.26^{\mathrm{c}}$ \\
\hline $6 \%$ & $0.87 \pm 0.06^{\mathrm{c}}$ & $5.85 \pm 0.09^{a}$ & $16.35 \pm 0.24^{\mathrm{a}}$ & $5.43 \pm 0.31^{\mathrm{a}}$ & $54.34 \pm 0.21^{\mathrm{a}}$ & $87.01 \pm 0.06^{\mathrm{a}}$ & $-0.72 \pm 0.58^{b}$ & $21.34 \pm 0.38^{\mathrm{d}}$ \\
\hline \multicolumn{9}{|l|}{$\mathrm{T} 3$} \\
\hline Control & $0.35 \pm 0.05^{\mathrm{a}}$ & $6.08 \pm 0.08^{\mathrm{a}}$ & $15.09 \pm 0.55^{\mathrm{a}}$ & $6.04 \pm 0.33^{\mathrm{a}}$ & $55.26 \pm 0.36^{\mathrm{a}}$ & $94.96 \pm 0.24^{\mathrm{a}}$ & $-0.85 \pm 0.29^{\mathrm{a}}$ & $15.45 \pm 0.32^{\mathrm{a}}$ \\
\hline Cut & $0.49 \pm 0.02^{\mathrm{b}}$ & $5.96 \pm 0.05^{\mathrm{a}}$ & $14.77 \pm 0.22^{\mathrm{a}}$ & $6.46 \pm 0.40^{\mathrm{a}}$ & $54.87 \pm 0.66^{\mathrm{a}}$ & $94.79 \pm 0.06^{\mathrm{a}}$ & $-0.62 \pm 0.36^{\mathrm{a}}$ & $16.19 \pm 0.19^{\mathrm{ab}}$ \\
\hline Cut & $0.42 \pm 0.03^{\mathrm{a}}$ & $5.96 \pm 0.02^{\mathrm{a}}$ & $15.33 \pm .38^{\mathrm{a}}$ & $5.99 \pm 0.17^{\mathrm{a}}$ & $54.48 \pm 0.31^{\mathrm{a}}$ & $92.07 \pm 0.21^{\mathrm{b}}$ & $-0.29 \pm 0.48^{a}$ & $25.20 \pm 0.48^{\mathrm{b}}$ \\
\hline $\begin{array}{l}\text { Crushed } \\
\text { T5 }\end{array}$ & $0.58 \pm 0.04^{b}$ & $5.92 \pm 0.02^{\mathrm{a}}$ & \multicolumn{6}{|c|}{$\mathrm{T} 5$} \\
\hline Control & $0.46 \pm 0.05^{\mathrm{a}}$ & $6.00 \pm 0.03^{\mathrm{a}}$ & $15.12 \pm 0.22^{\mathrm{a}}$ & $6.83 \pm 0.22^{\mathrm{a}}$ & $54.44 \pm 0.37^{\mathrm{a}}$ & $93.27 \pm 0.19^{\mathrm{a}}$ & $-1.04 \pm 0.41^{\mathrm{a}}$ & $14.21 \pm 0.19^{\mathrm{a}}$ \\
\hline $0.015 \%$ & $0.52 \pm 0.03^{\mathrm{a}}$ & $5.98 \pm 0.04^{\mathrm{a}}$ & $14.87 \pm 0.17^{\mathrm{a}}$ & $7.48 \pm 0.34^{\mathrm{a}}$ & $53.98 \pm 0.48^{a}$ & $93.36 \pm 0.17^{\mathrm{a}}$ & $-0.93 \pm 0.06^{\mathrm{a}}$ & $14.88 \pm 0.58^{\mathrm{a}}$ \\
\hline $0.020 \%$ & $0.64 \pm 0.02^{b}$ & $5.95 \pm 0.03^{\mathrm{a}}$ & $14.67 \pm 0.10^{\mathrm{a}}$ & $7.71 \pm 0.34^{\mathrm{a}}$ & $53.79 \pm 0.75^{a}$ & $93.29 \pm 0.11^{\mathrm{a}}$ & $-1.11 \pm 0.39^{a}$ & $15.13 \pm 0.34^{\mathrm{a}}$ \\
\hline $0.025 \%$ & $0.74 \pm 0.02^{\mathrm{c}}$ & $5.88 \pm 0.03^{\mathrm{a}}$ & $15.10 \pm 0.25^{\mathrm{a}}$ & $7.07 \pm 0.43^{\mathrm{a}}$ & $54.27 \pm 0.37^{a}$ & $93.36 \pm 0.28^{a}$ & $-0.87 \pm 0.33^{\mathrm{a}}$ & $14.20 \pm 0.64^{\mathrm{a}}$ \\
\hline \multicolumn{9}{|l|}{ T6 } \\
\hline Control & $0.44 \pm 0.05^{\mathrm{a}}$ & $5.99 \pm 0.03^{\mathrm{a}}$ & $15.75 \pm 0.25^{\mathrm{a}}$ & $5.65 \pm 0.28^{\mathrm{a}}$ & $54.71 \pm 0.24^{\mathrm{a}}$ & $93.39 \pm 0.04^{\mathrm{ab}}$ & $-0.8 \pm 0.12^{\mathrm{a}}$ & $14.19 \pm 0.12^{\mathrm{a}}$ \\
\hline $0.015 \%$ & $0.50 \pm 0.06^{\mathrm{a}}$ & $5.97 \pm 0.05^{\mathrm{a}}$ & $15.45 \pm 0.20^{\mathrm{a}}$ & $5.93 \pm 0.34^{\mathrm{a}}$ & $54.52 \pm 0.51^{\mathrm{a}}$ & $93.64 \pm 0.08^{b}$ & $-0.87 \pm 0.37^{\mathrm{a}}$ & $14.84 \pm 0.15^{\mathrm{b}}$ \\
\hline $0.020 \%$ & $0.62 \pm 0.07^{\mathrm{b}}$ & $5.94 \pm 0.02^{\mathrm{a}}$ & $14.84 \pm 0.25^{\mathrm{a}}$ & $6.29 \pm 0.11^{\mathrm{a}}$ & $54.16 \pm 0.42^{\mathrm{a}}$ & $93.19 \pm 0.16^{\mathrm{a}}$ & $-0.95 \pm 0.24^{\mathrm{a}}$ & $14.13 \pm 0.16^{\mathrm{a}}$ \\
\hline
\end{tabular}

Note: Data represented as mean \pm standard deviation of three replications. Values with different superscripts in a row are significantly different $(\mathrm{p} \leq 0.05)$ 
samples from each method of incorporation, was subjected to sensory evaluation by a panel of judges and the scores are tabulated in Table 2.

It is evident from the data of sensory scores in Table 2 that the extraction of cut lemongrass leaf in milk, obtained the highest score compared to all other samples, for most of the sensory parameters, including $\mathrm{CA}$, flavour and $\mathrm{OA}$, and the scores were statistically significant and comparable to that of control paneer sample. Hence, the addition of cut lemongrass leaf $(4 \% \mathrm{w} / \mathrm{v}$ addition) in to milk was selected as the optimized solution for the method of preparation of lemongrass flavoured paneer.

The optimized lemongrass flavoured paneer $(4 \% \mathrm{w} / \mathrm{v}$ addition in milk) had a proximate composition as follows: Total solids $44.74 \pm 0.77 \%$; Fat $-19.38 \pm 0.44 \%$; Protein $-21.25 \pm 0.15 \%$; Lactose $-2.47 \pm 0.05 \%$ and Ash $-1.64 \pm 0.44 \%$, which was found to be in agreement with the findings of Kanawjia et al., (1990) and Mistry et al. (1992). Hence, the composition of the optimized sample was established to be well within those reported in the literature.

\section{Effect of method of addition of lemongrass on the physico- chemical parameters of paneer}

The physico-chemical parameters of paneer samples in to which lemongrass has been added at different stages are being shown in Table 3. It may be noticed that the acidity of paneer samples gradually increased with the addition of lemongrass leaves and lemongrass oil in increased concentrations. The significant $(\mathrm{P}<$ 0.05 ) changes in acidity may be attributed to the incorporation of acidic components from lemongrass leaf as well as concentrated and freshly extracted lemongrass oil rich in acidic flavour compounds in to paneer. The $\mathrm{pH}$ values were also found to be slightly reducing with the increased addition of lemongrass leaf extract as well as oil. It may be observed that there was no significant difference for yield, solid losses and moisture among the control and experimental paneer samples. This may be expected because the only difference between control and experimental paneer was the addition of lemongrass leaf and oil to experimental samples.

Table 4 Textural attributes of paneer incorporated with lemongrass extract at different stages of preparation of paneer

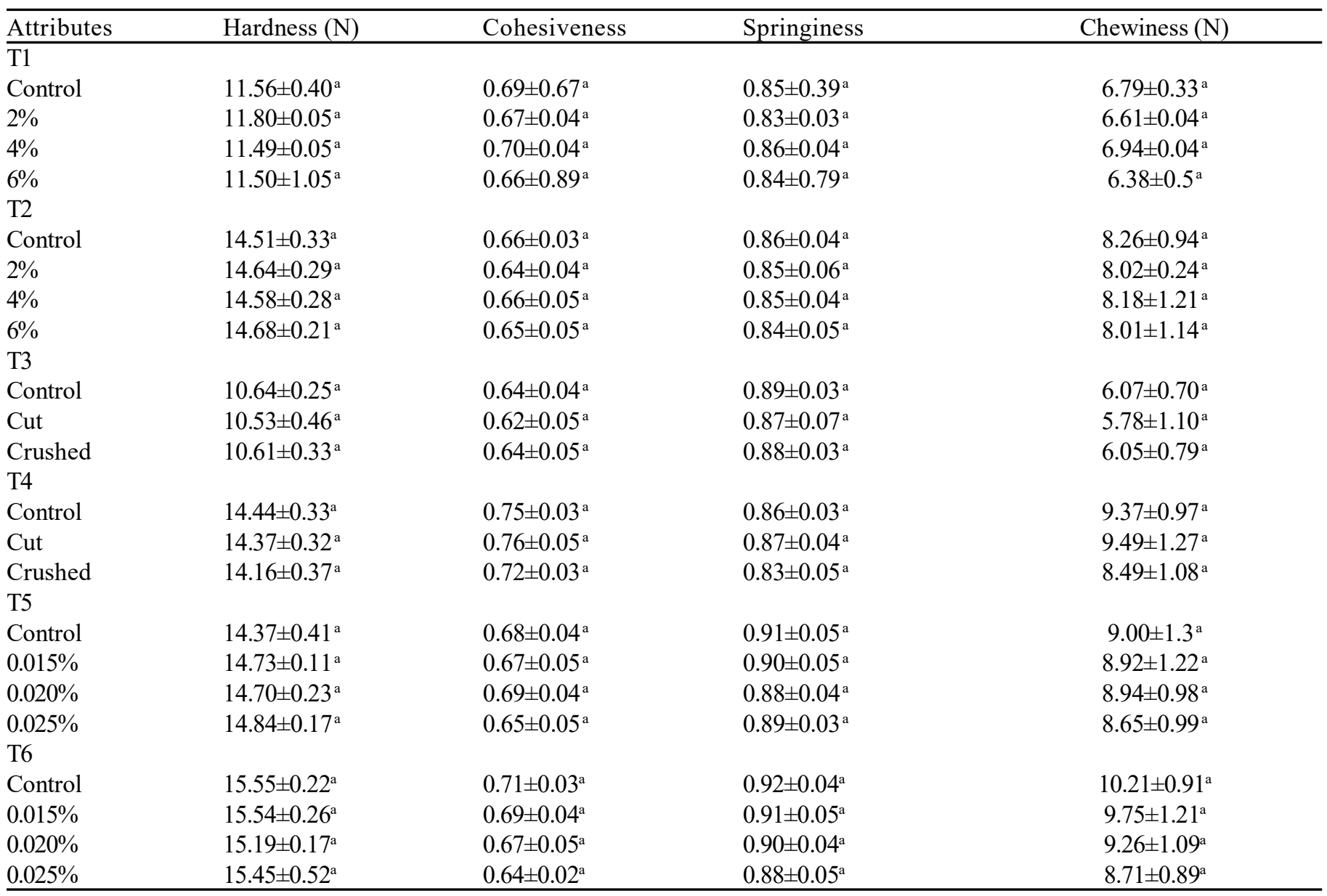

Note: Data represented as mean \pm standard deviation of three replications. Values with different superscripts in a row are significantly different ( $\mathrm{p}$ d" 0.05 ) 
The statistical analysis of the physico-chemical parameters at $5 \%$ level of significance indicated that the attributes such as acidity and $\mathrm{pH}$ were significantly affected, while the yield, solid losses and moisture parameters were not found to be changed by the addition of lemongrass leaves as well as oil for extraction in milk, chilled water and coagulant solution which is then utilized for paneer manufacture.

\section{Effect of method of addition of lemongrass on the colour characteristics of paneer}

The colour of food is one of the major attributes which affect the consumer perception and its quality, and it is also a powerful tool for quality control and marketing. The paneer samples incorporated with cut lemongrass were analyzed for changes in colour characteristics, L*[lightness, ranges 0 (black) to 100 (white)], a* [redness, ranges from +60 (red) to -60 (green)] and $b^{*}[$ Yellowness, ranges from +60 (yellow) to -60 (blue)], in values of the international colour system, by Scanner Adobe Photoshop method. The values were statistically analysed using one way ANOVA and summarized in Table 3.The statistical analysis indicates that $\mathrm{L}^{*}$ value was found to be following decreasing order, when lemongrass leaf was added in cut and crushed forms, which shows that paneer samples developed a darkened shade, with increased addition of leaf extract in to milk. The $\mathrm{a}^{*}$ and $\mathrm{b}^{*}$ value showed an increasing trend, along the levels of addition of extract of cut and crushed lemongrass leaf in to milk, which signifies that the paneer turns to a greenish shade, due to addition of extract of lemongrass leaf in to milk during its preparation. Similar results were obtained when lemongrass leaf extracts were used in dipping stage of paneer preparation.

The statistical analysis indicates that the values for colour attributes did not show any significant difference between the samples. It shows that the addition of lemongrass oil in to milk did not impart any significant effect, as far as colour characteristics are concerned.

\section{Effect of method of addition of lemongrass on the textural attributes of paneer}

Textural properties play an important role in the quality of paneer. Texture Profile Analysis (TPA) technique can be employed to determine attributes such as hardness, cohesiveness, gumminess, chewiness, springiness and fracturability of foods (Bourne, 1978). The mean values of hardness, cohesiveness, springiness and chewiness, of paneer incorporated with lemongrass by various methods, measured by using Texture Analyzer are presented in Table 4 . The hardness of paneer samples (control and experimental) ranged from $11.49 \pm 0.05 \mathrm{~N}$ to $15.55 \pm 0.22 \mathrm{~N}$, which however were not significantly different from each other. The same finding was observed for other parameters also. There was no significant difference between control and treatment samples of paneer with respect to cohesiveness, springiness and chewiness. Among the samples, the values for cohesiveness varied from $0.64 \pm 0.04$ to $0.76 \pm 0.05$, springiness ranged from $0.83 \pm 0.03$ to $0.91 \pm 0.05$ and chewiness averaged from $5.78 \pm 1.10-10.21 \pm 0.91 \mathrm{~N}$. The statistical analysis indicated that the addition of lemongrass leaf in both cut and crushed form as well as lemongrass oil did not impart any significant effect $(\mathrm{P}>0.05)$ on the textural attributes of paneer.

\section{Conclusions}

The demand of paneer is increasing in recent years, as it is a rich source of high quality animal protein, fat, minerals and vitamins. The utilization of lemongrass in paneer will be of great importance due to its flavoring property and it has the potential for the development of value added dairy products. It may be stated that production of paneer incorporated with lemongrass flavor can be commercialized on a large scale.

\section{Acknowledgements}

The first author gratefully acknowledges the financial assistance received from NDRI, Karnal (Deemed University), India in the form of Institutional Fellowship for carrying out the present project.

\section{References}

Almeida-Doria RF, Regitano-D'arce, Marisa AB (2000) Antioxidant level of rosemary and oregano ethanol extracts in soybean oil under thermal oxidation. Ciênc Tecnol Aliment 20:197-203

Amerine MA, Berg HW, Cruess WV (1967) The technology of winemaking. $2^{\text {nd }}$ eds. The AVI Publishing Company Inc.Connecticut

AOAC (2005) Official methods of analysis. Association of Official Analytical Chemists, Washington DC, USA. $18^{\text {th }}$ edition

Awad AAA, Omar MAM, EL-Hadidi AA, Mansour AIA (2005) Study on spreadable processed cheese. Mansoura Univ J Agri Sci30(10): 60856093

Bajwa U, Kaur J, Sandhu KS (2005) Effect of processing parameters and vegetables on the quality characteristics of vegetable fortified paneer. J Food Sci Technol 42:145-150

Bhattacharya DC, Mathur ON, Srinivasan M, Samilk D (1971) Studies on the method of production and shelf life of paneer (cooking type of acid coagulated cottage cheese). J Food Sci Technol8(9): 117-120

BIS (1981) Hand book of Food Analysis. SP: 18 (Part XI - 1981)Dairy products. Bureau of Indian Standards, New Delhi

BIS (1983) IS: 10484-Specification for paneer. Bureau of Indian Standards, New Delhi, pp 1-11

Bourne MC (1978) Texture profile analysis. Food Technol 32 (7): 62-66. Fandohan P, Hell K, Marasas WF(2008) Food processing to reduce mycotoxins in Africa. In: Leslie et al. (eds) Mycotoxins: Detection methods, management, public health and agricultural trade. CABI Publishing, Wallingford, UK, pp 302-309

Indian Dairy Industry Database 2018-2023, News provided by Research and Markets. Dublin, July 23,2018, 14:45 ET

Kanawjia SK, Roy SK, Singh S (1990) Paneer technology and its diversification. Indian Dairyman 42: 390-393

Koca N, Metin M (2004) Textural, melting and sensory properties of lowfat fresh kashar cheeses produced by using fat replacers. Int Dairy $\mathrm{J}$ 14(4):365-373 
Laswai HS, Mpanalile JJ, Silayo VCK, Ballegu WR(2009) Use of soybeans in food formulation in Tanzania. In: "Proceedings of the first national soybean stakeholders workshop" (Ed. Myaka FA, Kirenga G, Malema B), Morogoro- Tanzania, pp 52-59

Madsen MG, Grypa RD (2000) Spices, flavour systems, the electronic nose. Food Technol54: 44-46

Mathare SS, Bakal SB, Dissanayake TMR., Jain SK (2009) Effects of coagulation temperature on the texture and yield of soy paneer (tofu) J.Natn.Sci.Foundation Sri Lanka 37 (4):263-267

Mathur BN, Zanjad PN, Rao KVSS (1991) Paneer and tofu: An appraisal of product and process synergies. Indian Dairyman43: 407-41

Mistry CD, Singh S, Sharma RS (1992) Physico-chemical characteristics of paneer prepared from cow milk by altering its salt balance. Australian J Dairy Technol, 47:23-27

Natisri S, Mahattanatawee K, Thaiudom S (2014) Improving the flavor of soy ice cream by adding lemongrass or Pandan leaf extracts. Chiang Mai Univ J Natural Sci(Special Issue on Food): 469-482

Oraon L, Jana Atanu, Prajapati PS, Priyanka Suvera (2017) Application of herbs in functional dairy products - a review. J Dairy Vet Animal Res 5(3): 109-115
Rao BSS, Shanbhoge R, Rao BN, Adiga SK, Upadhya D, Aithal BK, Kumar MRS (2009) Alcoholic extract of Cymbopogon citratus against radiation induced DNA damage on V79 cells and free radical scavenging ability against radicals generated in vitro. Hum Exp Toxicol 28 (4):195-202

Sahu C, Choudhary PL, Patel S(2005) Techno-Economic feasibility of ready to serve whey based mango-herbal (lemongrass) beverage. Indian J Dairy Sci 58(4):258-263

Shelef LA, Naglik OA, Bogen BW (1980) Sensitivity of some common foodborne bacteria to the spices sage, rosemary and all spices. $\mathrm{J}$ Food Sci 45:1042-1044

Singh RS, Singh R, Shakya BR(2014) Impact of Turmeric addition on the Properties of Paneer prepared from different types of Milk. Int J Curr Engg Technol4(3): 1874-1883

Sutariya H, Rao KJ (2015) Utilization of lemongrass distillate in the preparation of yoghurt. Indian J Dairy Sci 68(6): 525-533

Vyawahare AS, Rao KJ (2012) Application of computer vision systems in colour evaluation of kunda: a heat desiccated dairy product. Int $\mathrm{J}$ Dairy Sci6(4):253-266 